\title{
Why Do Smallholder Famers In Four Tanzanian Districts Continue With Coffee Production Despite Fluctuating Prices?
}

\author{
David Gongwe Mhando \\ Associate Research Professor \\ College of Social Sciences and Humanities \\ Sokoine University of Agriculture \\ Post Box 3035, Morogoro \\ Tanzania \\ NtenguaSelemanMdoe \\ Professor \\ School of Agricultural Economic and Business Studies \\ Sokoine University of Agriculture \\ Post Box 3005, Morogoro \\ Tanzania
}

\begin{abstract}
Coffee production and marketing in Tanzania faces many challenges; price and weather variability, limited access to agricultural inputs, poor extension services, lack of irrigation, lack of credit facilities and land shortage which have decreased their capacity to consistently meet the supply of quality and required quantity. Despite of the challenges, coffee continues to be the main source of income to smallholder farmers. The study explores why coffee is still the most important crop to small scale farmers in four districts despite of the challenges they face. Household survey was conducted to 189 randomly selected coffeefarmers. The study found out that despite of the production and marketing challenges, coffee farming has remained a source of reliable income, a traditional crop and cultural symbol. Conclusions are reached that gaining from coffee production provides the means of investment to other food crops.
\end{abstract}

Keywords: coffee, smallholder farmers, fluctuating prices

\section{- Background Information}

There are two types of coffee produced in the world: Coffea arabica (Arabica coffee) and Coffeacanephora (var. Robusta). While coffee production is concentrated in the southern hemisphere, it is consumed more in the northern hemisphere. During the 2016/17 season, global coffee production was reported to be 158.93 million bags: 98.84 million bags (62\%) of Arabica and 60.10 million bags (38\%) of Robusta. In terms of continent-wide production, South America was the leading producer (45\%), Asia and Oceania produced 30\%, North America's Mexico and Central America regions produced 14.5\%, and Africa produced 11\%. While 10 countries produced $88 \%$ of all coffee in the world, Brazil was the leading producer with about 55 million Bags (TCB, 2017).

\subsection{Importance of coffee in Tanzania}

Coffee is one of Tanzania's primary agricultural export crops representing about 5\% percent of total exports, $24 \%$ of traditional cash crops and generating export earnings averaging 100 million USD per annum over the last 30 years (about 145 million USD in 2011). However, the share of coffee in total exports had gradually declined from $7 \%$ in 2001 to around $3 \%$ in the last few years. The coffee industry in Tanzania provides direct income to more than 400,000 families who own small farms and benefits indirectly the livelihoods of estimated 2.4 million Tanzanians (TCB, 2017). Tanzania produces two types of coffee, Arabica and Robusta. The major Arabica growing regions are Kilimanjaro/Arusha, Songwe, Mbeya, and Ruvuma. Other Arabica growing regions include Tanga, Iringa, Morogoro, Kigoma, Manyara, Mwanza, Katavi and Mara. Robusta is mainly produced in the Kagera region. It is estimated that 275,000 hectares are under coffee cultivation; large private estates reach yields up to $2.500 \mathrm{~kg} / \mathrm{ha}$ (with irrigation and fertilizers), and smallholders reach an average of $250-300 \mathrm{~kg} / \mathrm{ha}$ (TCB, 2017). 
Smallholder households, with $0.5-1.0$ hectares, are responsible for $90 \%$ of coffee production; the remaining $10 \%$ is produced by some 110 large estates. Smallholder growers produce coffee mainly for commercial purposes and domestic consumption of coffee has decreased from $7 \%$ in 2000/01 to 4.8\% in 2015/16 (TCB, 2017).

Annual per capita coffee consumption in Tanzania is 0.06 kilo, and 7-8 per cent of the country's total coffee production is locally processed and consumed. Although the contribution of other sectors, such as minerals and tourism $(25 \%$ in $2015 / 16)$ is currently greater than that of coffee, coffee is still one of the most important cash crops in Tanzania. However, export shares are decreasing; for example, it decreased from $7.2 \%$ in 2001 to about $3.2 \%$ in 2017 . Factors associated with this decrease include increasing share from other sectors and decreasing prices in the world market. Other factors which have contributed to the decline of its importance include price fluctuation (high production cost compared to income) (Mhando, 2007), limited extension services, climate change and limited uses of agricultural inputs. The annual coffee production in Tanzania fluctuated from 58,175.1 tons in 2000 to 47,591 tons in 2018 (TCB, 2017).

Despite the decreasing importance of coffee in Tanzania as an important source of foreign exchange as compared with other sectors, limited extension services and increasing costs of production and other associated challenges, smallholder farmers have continued with coffee cultivation on their own land with fluctuating income and limited support. The present study thrives to explore why coffee farmers in four districts have continue with coffee cultivation despite the challenges facing them.

\section{2: The Role Of Production And Marketing In Agriculture}

Production and marketing are both important parts of a total business system aimed at providing the consumer with need-satisfying goods and services. Marketing is defined as the series of services involved in moving a product (or commodity) from the point of production to the point of consumption (Dixie, 1989). It refers to the process of price-decision for a good by seller and buyer together, and markets are the places where such decisions take place (Ellis, 1996). It involves planning, organizing, directing, and handling agriculture products to satisfy the producer and the consumer. Marketing plays an important role in stimulating production and consumption and accelerates the pace of economic development of a country (Mahanta and Konwar, 2014). It can signal the needs of both consumers and industrial users and gives integrative force that matches production to customer needs. Markets can be perfect or imperfect depending on buyers and sellers' influence on price formation, and integrated or fragmented depending on availability of transport and communication among the market participants (Masanjala, 2005). An efficient marketing system can provide better prices to producers and improve the availability of competitive prices to consumers (Tracey-White, 2003).

On the other hand, production is the process of combining and coordinating inputs (resources and factors of production) in the creation of goods and services. Agricultural production involves investment of scarce resources on various inputs and production processes to produce crops of the choice and supply the produces to market. Such action (investment) by farmers will depend on price signal (demand chain) and physical transmission (supply chain) functions of marketing systems (Ellis, 1996). Price signal transmission depends on the number and size of participants, information system and the physical infrastructure (Sapkota, and Pokhrel, 2010). Production will tend to vary with the level of input usage. In an economy, production and marketing must go hand in hand. Whenever there is a market power on one side of a transaction, the resulting price does not equate the marginal cost of production (Ellis, 1996). A fair and high price available to farmer has positive impact on farm production decisions, which leads to an expansion of the production program and its improvement at farm level. In contrast, an unfair and low price available to farmer affects farm production decision negatively and renders him/her reluctant to continue the production program (Sapkota, and Pokhrel, 2010). Therefore, marketing is used to direct production in accordance with clear signals from the marketplace (FA0, 2008).

\section{3: Methodology}

This study was conducted in four coffee cultivating districts in Tanzania, namely Mbinga, Mbozi, Kyerwa and Tarime. The four districts were sampled from two zones that are leading in coffee production in Tanzania: Mbozi and Mbinga in the southern zone, Kyerwa and Tarime in the western zone. These districts represent zones that produce Arabica (southern) and Robusta (western). Household survey was conducted to 189 randomly selected farmers from four coffee growing districts. 
In addition, interviews were conducted with key informants (district officials who deal with coffee) and stakeholders (Coffee Management Services, Tutunze Kahawa, Café Africa) from the study areas were consulted.

\section{4: Results and Discussions}

\subsection{Current situation of coffee production and marketing in Tanzania}

The agriculture sector is affected by different causes that can lead to low productivity (Masood et al., 2012). Agricultural production decreases due to many factors like climate change, the degradation of the land, low soil fertility, land ownership, illiteracy, lack of good quality of seeds and fertilizers, traditional farming methods, technological factors, lack of entrepreneurship in agricultural zones, weak agrarian structure, internal and international migration and droughts (Masood et al., 2012). Productivity of land is a very important factor of agriculture because it is the most permanent and fixed factor among the three categories of inputs; land, labour and capital (Sreekanth et al; 2017). Over the last 40 years, crop productivity has risen throughout the rest of the world yet has remained stagnant in Africa (Jayne 2010). This is the case in Tanzania where coffee production is very low.

Table 1: Coffee output per household and yield per hectare in 2015/16 farming season

\begin{tabular}{|c|c|c|c|c|}
\hline \multicolumn{2}{|l|}{ District } & \multirow{2}{*}{$\begin{array}{c}\begin{array}{c}\text { Coffee output } \\
\text { (kg/household) }\end{array} \\
436.64\end{array}$} & \multirow{2}{*}{$\begin{array}{c}\begin{array}{c}\text { Coffee Yield } \\
(\mathrm{kg} / \mathrm{ha})\end{array} \\
554.98\end{array}$} & \multirow{2}{*}{$\begin{array}{c}\text { Yield per Tree } \\
(\mathrm{kg} / \text { tree })\end{array}$} \\
\hline Mbinga & Mean & & & \\
\hline & Minimum & 20.68 & 51.08 & 0.08 \\
\hline & Maximum & 1980.00 & 1553.98 & 2.20 \\
\hline & Std. Deviation & 367.447 & 250.58 & 0.54 \\
\hline \multirow[t]{4}{*}{ Mbozi } & Mean & 437.46 & 422.25 & 0.378 \\
\hline & Minimum & 8.80 & 3.62 & 0.03 \\
\hline & Maximum & 3634.40 & 1745.30 & 1.10 \\
\hline & Std. Deviation & 583.42 & 253.39 & 0.35 \\
\hline \multirow[t]{4}{*}{ Tarime } & Mean & 150.34 & 405.78 & 0.78 \\
\hline & Minimum & 19.80 & 27.17 & 0.16 \\
\hline & Maximum & 1078.00 & 1956.24 & 2.03 \\
\hline & Std. Deviation & 175.69 & 378.38 & 0.68 \\
\hline \multirow[t]{4}{*}{ Karagwe } & Mean & 397.98 & 539.68 & 2.98 \\
\hline & Minimum & 25.20 & 24.45 & 0.36 \\
\hline & Maximum & 6480.00 & 2600.91 & 7.56 \\
\hline & Std. Deviation & 860.76 & 518.14 & 2.62 \\
\hline \multirow[t]{4}{*}{ Kyerwa } & Mean & 440.35 & 731.80 & 2.62 \\
\hline & Minimum & 36.00 & 88.92 & 0.73 \\
\hline & Maximum & 1323.00 & 2091.40 & 4.70 \\
\hline & Std. Deviation & 338.62 & 513.00 & 1.46 \\
\hline
\end{tabular}

Coffee output per household and yield per hectare was low and varied significantly among coffee producing households within and across the four sampled districts. On average the output per household for Arabica coffee varied from $150.34 \mathrm{~kg}$ in Tarime district to $437.46 \mathrm{~kg}$ in Mbozi district, while yield varied from $405.78 \mathrm{~kg} / \mathrm{ha}$ in Tarime district to $554.98 \mathrm{~kg} / \mathrm{ha}$ in Mbinga district (Table 1). In all three Arabica producing districts, coffee yield in the 2015/16 farming season varied significantly. In Mbinga, yields varied from $51.08 \mathrm{~kg} / \mathrm{ha}$ to $1,555.98 \mathrm{~kg} / \mathrm{ha}$. In Mbozi and Tarime districts, the coffee yield variation was even high. It varied from $3.62 \mathrm{~kg} / \mathrm{ha}$ to $1,745.30$ $\mathrm{kg} / \mathrm{ha}$ in Mbozi district, and from $24.17 \mathrm{~kg} / \mathrm{ha}$ to 1,956.24 in Tarime district. The yield for Arabica coffee across the three sample districts that grow Arabica coffee are far below the average yield of 2,500 $\mathrm{kg}$ ( 2.5 tons) per ha in Brazil. For Robusta coffee, average coffee yield in the 2015/16 farming season varied from $518.14 \mathrm{~kg} / \mathrm{ha}$ in Karagwe district to $731.80 \mathrm{~kg} / \mathrm{ha}$ in Kyerwa district. In both Robusta growing districts, coffee yields varied 
greatly from $24.45 \mathrm{~kg} / \mathrm{ha}$ to $2,600.91$ in Karagwe district and from $88.92 \mathrm{~kg} / \mathrm{ha}$ to $2,091.40 \mathrm{~kg} / \mathrm{ha}$ in Kyerwa district (Table 1).These Robusta yields are far below the yield of $6,000 \mathrm{~kg} / \mathrm{ha}$ (6 tons/ha) achieved in Vietnam, a major Robusta producing country in the world. This is an indication that productivity is still very low.

The main reasons of low productivity include lack of inputs such as fertilizers, and a lack of appropriate improved varieties that are drought and disease resistance. Youth who grew up in coffee cultivation areas have developed coffee cultivating culture and are ready to invest in coffee cultivation (Mbozi and Mbinga districts) but they still need more support from the government in terms of extension services or even provision of agricultural inputs. Other reasons are poor investment in coffee production due to poverty and withdraw of youth labor from the coffee sector. It has been reported that coffee is regarded as the crop of old people in some areas in Tanzania and thus, there are efforts to turn this tide and bring the youth into coffee cultivation. Café Africa is one of the NGOs which has initiated a project aimed at involving Katavi Region youth in coffee cultivation. Nevertheless, it is common for women to work in commercialized crops and women's direct control over income from these crops is much less than that of men and frequently even disproportional to their labor input into the crops (Masanjala, 2008)

\subsection{Challenges of coffee production in Tanzania}

In general, smallholder farmers have limited resource endowment relative to other farmers in the sector. The main characteristics of production systems of smallholder farmers are outdated technologies, low returns, high seasonal labour fluctuations and women playing a vital role in production (Mhando, 2007). Coffee farmers face various challenges that impede their growth and ability to effectively compete in the domestic and export markets. However, in the study areas farmers have been noted to continue with coffee cultivation despite these odds. This section explores challenges of producing coffee among the smallholder farmers in Tanzania.

\subsubsection{Challenges of production varieties used by respondents}

Table 2: Varieties of coffee cultivated by respondents

\begin{tabular}{|l|l|c|c|c|c|}
\hline \multicolumn{5}{|c|}{ Coffee Varieties } \\
\hline District & & Conventional & Hybrid & $\begin{array}{c}\text { Both Conventional and } \\
\text { Hybrid }\end{array}$ & Total \\
\hline \multirow{3}{*}{ Mbinga } & Frequency & 74 & 1 & 25 & 100 \\
\cline { 2 - 6 } & Percentage & 20 & 0.3 & 6.8 & 27.0 \\
& Frequency & 67 & 3 & 20 & 90 \\
& Percentage & 18.1 & 8 & 5.4 & 24.3 \\
\hline
\end{tabular}

One of the reasons for poor agricultural performance in many developing countries is a lack of progress in improving traditional plant varieties over the centuries (WIPO, 2010). It has been argued that modern plant breeding has enabled yields to increase substantially. It is estimated that improved varieties have contributed to more than 50\% of overall yield increases for important crops in Europe (WIPO, 2010). Coffee famers in Tanzania do not often use improved varieties, as they continue using older inherited varieties that were used by their parents. Respondents (70.8\%) have reported their use of old and aging conventional varieties, which have a great effect in coffee productivity (Table 2). It has been reported as well that conventional varieties are easily attacked by Coffee Berries Diseases (CBD) and coffee leaf rust (TaCRI, 2017). The two diseases are the main challenges for Arabica producers and they are very expensive to treat. Despite the presence of alternative disease-resistant varieties, farmers have continued to use the conventional varieties. Farmers claimed that prices of a seedling of newly introduced variety are higher (TZS 300) compared to conventional varieties, which are sold at TZS 100. A higher water requirement is another reason indicated by the producers as to why they have continued to use the old conventional varieties. In fact, shifting to the new hybrid varieties will not only reduce the costs of production, but will increase productivity, quality, and ultimately income to the smallholders.

\subsubsection{Availability of extension services}

Agricultural extension services include the provision of farmers with knowledge, information, experiences and technologies needed to increase and sustain productivity in order to improve wellbeing and livelihoods (Raidimi, 2017). Delivery of quality agricultural extension services in Tanzania has been a center of attention for a long time (Daniel, 2013). Agricultural extension services in Tanzania have been entrusted to local government authorities to ensure effective participation of beneficiaries and to motivate private sector involvement in service 
delivery (Raidami, 2017). However, there is a failure of the local government to provide much needed extension services to the coffee producers. This has resulted in farmers continuing to use conventional methods of coffee cultivation in the dynamic coffee market. The gap left by the government extension services has been utilized well by multinational companies who have penetrated the coffee industry in Tanzania up to the farm gates.

Thus, with the lack of information on coffee marketing and developments in the globe coffee industry, farmers have become the victims. Farmers lack basic knowledge about trends of the world market and how it is likely to affect them. URT (2013) reported that there were 7,974 extension workers against the requirement of 15,082 extension workers at village and ward levels, with only $42 \%$ of farmers receiving extension services. This means that most of the farmers have continued to cultivate coffee by using inherited knowledge from their parents which results to low harvest.

During the study it was reported that an extension officer has visited less than $50 \%$ of coffee farmers. It was reported that only $48.4 \%$ of the sample households have been visited at least twice a year. Those who were rarely visited account for $28.5 \%$ of the sample households (Table 3 ).

Table 3: Frequency of extension officer visit to farmers

\begin{tabular}{|l|l|c|c|c|c|}
\hline \multirow{2}{*}{ Tarime } & Frequency & 50 & 16 & 14 & 80 \\
\cline { 2 - 6 } & Percentage & 13.5 & 4.3 & 3.8 & 21.6 \\
\hline \multirow{3}{*}{ Karagwe } & Frequency & 43 & 1 & 17 & 61 \\
\cline { 2 - 6 } & Percentage & $13.5 \%$ & $4.3 \%$ & $3.8 \%$ & $16.5 \%$ \\
\hline \multirow{3}{*}{ Kyelwa } & Frequency & 28 & 0 & 11 & 39 \\
\cline { 2 - 6 } & & & & & $10.5 \%$ \\
\cline { 2 - 6 } & Percentage & 7.6 & 0.0 & 3.0 & 370 \\
\hline \multirow{2}{*}{ Total } & Frequency & 262 & 21 & 87 & 100 \\
\cline { 2 - 6 } & Percentage & $70.8 \%$ & $5.7 \%$ & $23.5 \%$ & \\
\hline
\end{tabular}

Source: Survey Data

\subsubsection{Limited input use and crop husbandry}

Limited use of quality inputs and deficient husbandry practices are also referred to as production obstacles in coffee farming. Before the abolition of cooperatives in Tanzania, farmers received agricultural inputs on a loan basis and the balance was paid after the farmers sold their crops (Mhando, 2017). After trade liberalization, farmers are supposed to purchase agricultural inputs on their own and as a result, most of the coffee farmers cannot afford to purchase and use agricultural inputs. Likewise, some of the farmers do not follow GAP, with resulting lowered productivity of coffee. For example, productivity in Mbozi is 250 grams of parchment coffee per tree, but with GAP farmers could increase it to 2-3 kilograms of parchment coffee.

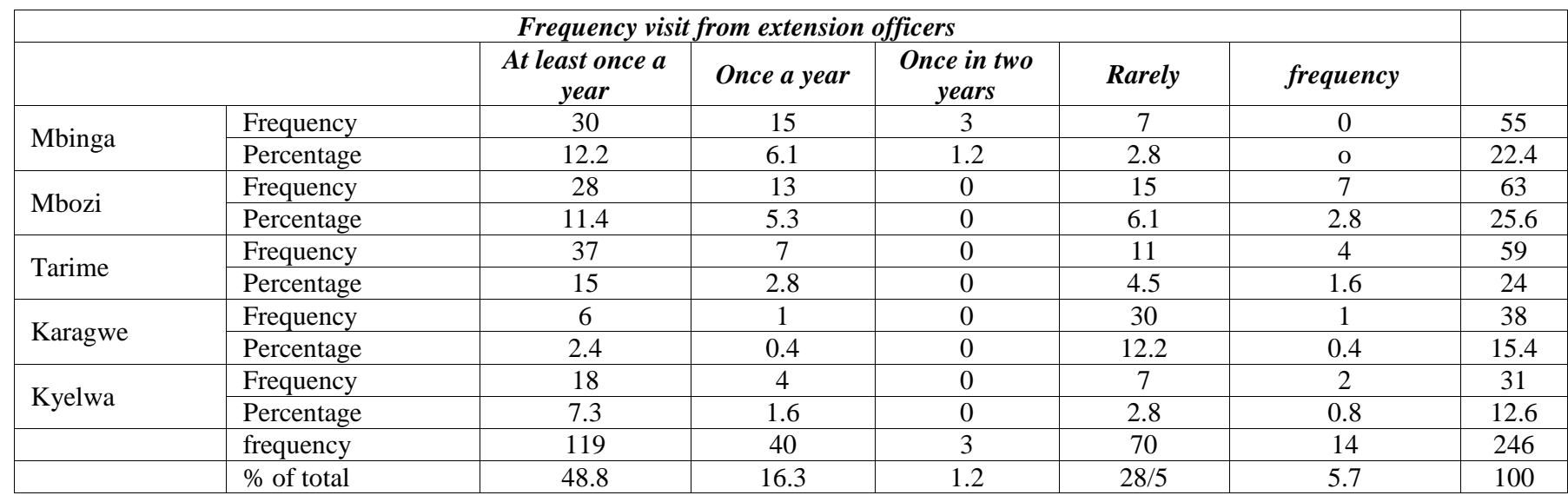

Agrochemicals (fertilizer, pesticides and herbicides) and manure were largely used in Mbozi and Mbinga Districts in the southern coffee growing zone but were used much less in the western districts. Except for timely weeding, very few farmers practiced simple, but important, husbandry practices like mulching and timely pruning of their coffee tree (Table 4). 
Not only has low use of fertilizers and other inputs has reduced coffee production over the years but also use of the fake agricultural inputs has greatly contributed to decrease in yields. Fertilizer education and training programs in East Africa were found to boost average incomes by 61\% (Johnes, 2015). The government needs to ensure the right type of fertilizers are available at the right price, and at the right times

\subsubsection{Lack of credits}

Table 5: Inputs and husbandry practice in the farm

\begin{tabular}{|c|c|c|c|c|c|c|c|c|c|c|c|}
\hline & & & \multicolumn{8}{|c|}{ Inputs and husbandry practices in farm } & \multirow[b]{2}{*}{ Total } \\
\hline & & & $\begin{array}{l}\text { Chemical } \\
\text { fertilizer }\end{array}$ & Manure & Pesticides & Herbicides & Irrigation & Mulching & $\begin{array}{l}\text { Timely } \\
\text { pruning }\end{array}$ & $\begin{array}{c}\text { Timely } \\
\text { weeding }\end{array}$ & \\
\hline \multirow[t]{10}{*}{ District } & Mbinga & Frequency & 100 & 89 & 99 & 63 & 5 & 42 & 92 & 85 & 575 \\
\hline & & $\%$ of Total & 5.8 & 5.1 & 5.7 & 3.6 & .3 & 2.4 & 5.3 & 4.9 & 33.1 \\
\hline & Mbozi & Frequency & 90 & 74 & 86 & 76 & 25 & 33 & 87 & 76 & 547 \\
\hline & & $\%$ of Total & 5.2 & 4.3 & 5.0 & 4.4 & 1.4 & $1.9 \%$ & $5.0 \%$ & $4.4 \%$ & $31.5 \%$ \\
\hline & Tarime & Frequency & 9 & 76 & 6 & 1 & 7 & 66 & 64 & 72 & 301 \\
\hline & & $\%$ of Total & .5 & 4.4 & .3 & 0.1 & 0.4 & 3.8 & 3.7 & 4.1 & 17.3 \\
\hline & Karagwe & Frequency & 1 & 28 & 1 & 3 & 0 & 44 & 57 & 59 & 193 \\
\hline & & $\%$ of Total & 0.1 & 1.6 & 0.1 & 0.2 & 0.0 & 2.5 & 3.3 & 3.4 & 11.1 \\
\hline & Kyerwa & Frequency & 0 & 11 & 0 & 1 & 0 & 32 & 38 & 37 & 119 \\
\hline & & $\%$ of Total & 0.0 & .6 & 0.0 & 0.1 & 0.0 & 1.8 & 2.2 & 2.1 & 6.9 \\
\hline \multirow[t]{2}{*}{ Total } & & Frequency & 200 & 278 & 192 & 144 & 37 & 217 & 338 & 329 & 1735 \\
\hline & & $\%$ of Total & $11.5 \%$ & 16.0 & 11.1 & 8.3 & 2.1 & 12.5 & 19.5 & 19.0 & 100.0 \\
\hline
\end{tabular}

Many smallholders are excluded from productivity-enhancing financial services and are unable to secure much needed fixed and working capital, which ranges from land, machinery, high-yielding seeds, and fertilizer (Schengen, 2013). Smallholder financing has limited number of loans from commercial banks to agriculture and therefore limited access to loans is just one factor affecting their poverty (Banerjee and Duflo 2007).

The reasons for limited finance in agriculture are numerous: the dispersed demand and high cost of service in low-population areas; the weak administrative capacity of rural banks; agriculture-specific covariate risks such as variable weather patterns, pests, and price fluctuations; and lack of formally defined property and land-use rights support collateral demands for loans (Schengen, 2013). In Tanzania, high interest rates for loans (20\%), combined with fluctuating prices, make farmers hesitate to take loans from commercial banks like CRDB and NMB. Fluctuation of prices hinders farmers from investing in coffee because they are not sure if they will get return from their investment. High interest rates put farmers in a trap. Therefore, farmers do not cultivate coffee for commercial purposes, but in order to continue with what they have been doing over the years. At the same time, most of the land in Tanzania is untitled; and thus, farmers cannot use their land as collateral to access loans from the Banks. Missing land deeds disqualifies farmers from getting bank loans. Easy process of obtaining land deeds to farmers and initiation of an agricultural bank, which would take on board the challenges that face farmers, could be steps in the right direction.

\subsubsection{Marketing challenges}

There are several challenges relating to coffee marketing in Tanzania. There is overdependence on external markets: over 95\% of all coffee produced in Tanzania is exported. When the price increases, farmers invest in coffee cultivation but when the price decreases, farmers are discouraged from investing and taking care of their coffee plots.

Farmers have reported a lack of market information and, as a result, they end up selling their coffee without understanding the prevailing prices. Although the Coffee Industry Regulation Act prohibits trading coffee without a license, there are middlemen in the villages who take advantage of the farmers' vulnerabilities and collect coffee from farmers at lower prices (Mhando, 2017). Both the local government and the TCB have failed to control these middlemen, even though the practices reduce the motivation of the farmers to continue with production and, thus, a smaller amount of coffee is produced. Similarly, smallholder farmers depend on income from coffee for their livelihoods and will sell to whoever offers higher prices. The presence of a cross-border black market for coffee from Kagera to Uganda has been reported, although there is no official figure of the amount involved. Rough estimates show that $40 \%$ of coffee produced in Kagera is sold across the border in Uganda. Coffee trade and prices are highly determined by coffee quality, which is a manifestation of GAP and processing. 
Unlike the estates, a smallholder farmer works at the individual level and, thus, the quality of their coffee differs. Those who work hard to produce high quality coffee would like to see their efforts rewarded and are motivated to continue with the production of high quality coffee. However, traders pay uniform (blanket) prices regardless of quality (Mhando, 2013). This is likely to impact the morale of the farmers who might otherwise work hard and produce high quality coffee for a higher monetary gain.

Farmers depend on cooperatives inr their production and marketing processes. However, bureaucracy within the cooperative structure fails to understand the business model of coffee, which is very crucial. Cooperatives are not flexible with changing prices as opposed to PCBs. At the beginning of the season, the prices are higher because traders have orders and they compete to purchase coffee to fulfill their orders. In the middle of the seasons the prices fall. Societies should pay to its members the same prices fetched at the auction, and not simply blanket prices. PCBs take advantage of these cooperatives in making profit.

\subsection{Why is coffee still the most important source of income despite all the challenges faced by farmers?}

\subsubsection{Relative importance of coffee}

Revenue from coffee farming has been reported to be an important source of income to smallholder farmers in the study areas. Farm income refers to profits and losses incurred through the operation of a farm. Production of cash crops contributes to livelihood diversification and poverty alleviation by directly increasing the farm household's income earning potential, which, in turn, increases the household's spending potential. Since cash crops earn higher value than food crops, the production of cash crops enables the farm household to obtain more income for their own food production (Masanjala, 2008). Coffee production allows smallholder farmers access to a broader means of increasing their incomes, and simultaneously, provides farmers with a means of financing the other food crop. This is because the introduction of coffee is accompanied by improved delivery of inputs on credit through traders, and participation in production has enabled farm households to acquire resources for use in other elements of the crop mix (Dorwardet al., 1998). Unlike food crops, coffee cultivation needs an institutional arrangement that will promote the easy availability of agricultural inputs, extension services and markets. To initiate and review coffee cultivation, TCB has linked farmers in new and potential coffee growing areas with markets: Maskati, Bunduki and Maguruwe in Morogoro; Busekelo in Mbeya; and Bushoke in Mwanza. These areas provide potential for using new hybrid coffee seedlings.

Table 6: Main Sources of household income (\%)

\begin{tabular}{|l|c|c|c|c|c|c|}
\hline Crop & Mbinga & Mbozi & Tarime & Karagwe & Kyerwa & Total \\
\hline Coffee & 98.1 & 93.3 & 84.6 & 78.2 & 89.7 & 90.2 \\
\hline Banana & 0.0 & 0.0 & 1.3 & 10.9 & 0.0 & 1.9 \\
\hline Maize & 1.9 & 3.3 & 10.3 & 1.8 & 0.0 & 3.8 \\
\hline Vegetables & 0.0 & 2.2 & 1.3 & 0.0 & 0.0 & 0.8 \\
\hline Livestock & 0.0 & 0.0 & 2.6 & 0.0 & 0.0 & 0.5 \\
\hline Beans & 0.0 & 1.1 & 0.0 & 9.1 & 10.3 & 2.7 \\
Total & 100.0 & 100.0 & 100.0 & 100.0 & 100.0 & 100.0 \\
\hline
\end{tabular}

Source: Research data

Even though food crops are important to household food security and income, coffee remains the most important contributor to the household income as reported by $90.2 \%$ of all the respondents (Table 6). As the data from Table 7 indicates, coffee is still the most popular crop and source of income as indicated by 81.2 and $88.2 \%$ of the respondents. This means that coffee is still an important crop among the farmers in the coffee producing zones. Because coffee is a traditional crop, it is perceived to be an important main source of income and a cultural symbol; a Matengo farmer is just one example. During the study, it was reported that a Matengo household in Mbinga District is respected based on availability of a well-attended coffee farm, without which one would not be respected, nor deemed creditworthy in the village.

Most of the predicted gains in welfare due to coffee production are based on the notion of comparative advantage and specialization in agricultural production. Thus, despite decreasing prices and the associated challenges, farmers have continued to value the crop. Besides being a major source of income, coffee is a leading crop in providing the coffee growing households' reliable income in the past five years (Table 6). While having a diverse livelihood portfolio can reduce the risk of market volatility, the risk of food insecurity and smooth cash flow over time, for SHF in Songwe and Mbeya Regions, coffee is needed to cover school expenses, household expenses 20 
(including, but not exclusively, food expenses) and to buy inputs for use on coffee and essential staple crops. The study by AGRA/IDH (pers comm) found that the cash income from the sale of staples and other crops within a local market was not enough to cover the cost of inputs for these crops.

Table 7: Leading crop or livestock enterprise in providing reliable income in the past five years (\%)

\begin{tabular}{|l|c|c|c|c|c|c|}
$\begin{array}{l}\text { Crop/Livestock } \\
\text { enterprise }\end{array}$ & Mbinga & Mbozi & Tarime & Karagwe & Kyerwa & Total \\
\hline Coffee & 92.2 & 93.3 & 68.4 & 81.8 & 89.7 & 85.6 \\
\hline Banana & 0.0 & 0.0 & 2.6 & 7.3 & 0.0 & 1.7 \\
\hline Maize & 2.9 & 3.4 & 21.1 & 1.8 & 0.0 & 6.4 \\
\hline Vegetables & 0.0 & 1.1 & 1.3 & 0.0 & 0.0 & 0.6 \\
\hline Livestock & 4.9 & 2.2 & 3.9 & 0.0 & 0.0 & 2.8 \\
\hline Beans & 0.0 & 0.0 & 0.0 & 9.1 & 10.3 & 2.5 \\
Total & 100.0 & 100.0 & 100.0 & 100.0 & 100.0 & 100.0 \\
\hline
\end{tabular}

Source: Research data

\subsubsection{Lack of alternative sources of income}

Although farmers have been noted to continue with coffee production despite its challenges, it was noted as well that farmers lack alternative sources of income, which would assist them in getting away from coffee cultivation. Almost all respondents have indicated that they have limited alternatives and thus they are still cultivating coffee despite all the odds.

\subsubsection{Expansion of land under coffee}

Relative to other areas of the developing world, Africa has been a continent of ample land and scarce labor. Between 1960 and 2000, FAO reported that the amount of arable land under cultivation (including permanent crops) has risen marginally, but the population of households engaged in agriculture has tripled (Saris, et al, 2010). This has caused a steady decline in the ratio of arable land to agricultural population these findings reinforce the views that over time rural populations tend to cluster in areas where agro-ecological conditions are favorable and access to markets and services are best, leading to a highly nucleated pattern of settlement and land shortage (Jayne et al., 2010). At the same time, there are still large tracts of unallocated land in the more remote parts of some regions, but the economic value of this land is limited because of the lack of access to markets and services. This relates to Tanzania where there is still much unused arable land. Thus, despite the shortage of land in the traditional coffee growing areas in Tanzania, new areas have been opened for coffee production. Table 8 shows new land area opened for coffee production in Karagwe and Kyerwa Districts. This could explain the increasing coffee production in Kagera region a few years ago despite challenges like climate change and smuggling of coffee to neighboring countries.

Table 8: New areas opened for coffee production in Karagwe and Kyerwa districts

\begin{tabular}{|l|c|c|c|}
\hline District & $\mathbf{2 0 1 3 / 1 4}$ & $\mathbf{2 0 1 4 / 1 5}$ & $\mathbf{2 0 1 5 / 1 6}$ \\
\hline Karagwe & 475 & - & 67 \\
\hline Kyerwa & 17,793 & 18,030 & 18,666 \\
\hline
\end{tabular}

Source: Karagwe and Kyerwa District Offices

Even though there is a land constraint in some of the study districts, some of the respondents have reported expanding their coffee farms. Overall, 35\% of the sample households reported that they expanded land under coffee in the past five years.

The proportion of households that expanded land used for coffee varied from $26 \%$ and $50 \%$ in Tarime and Kyerwa districts respectively. Only 5\% of the sampled farmers reported reduction of land used for coffee and about $60 \%$ of the sample households maintained the land under coffee cultivation in the past five years (Table 9). The high proportion of farmers who expanded coffee farms relative to those who reduced further expansion underscores the importance of coffee relative to other crops in the study districts. Jayne (2010) reported that there is a strong relationship between access to land and household income. This indicates that the income of those farmers who expanded their farms is going to increase as it is noted that land holding size is positively related to variables signifying productive farming potential and wealth, which is most likely correlated with initiative and effort. 
Table 9: Proportion of sample household that have expanded or reduced coffee farms in the past five years $(\%)$

\begin{tabular}{|l|c|c|c|c|c|c|}
\hline District & Mbinga & Mbozi & Tarime & Karagwe & Kyerwa & Total \\
\hline Expanded & 40.0 & 30.5 & 26.0 & 38.2 & 50.0 & 35.2 \\
\hline Reduced & 1.1 & 1.2 & 9.1 & 14.5 & 0.0 & 5.0 \\
\hline Constant & 58.9 & 68.3 & 64.9 & 47.3 & 50.0 & 59.8 \\
\hline Total & 100.0 & 100.0 & 100.0 & 100.0 & 100.0 & 100.0 \\
\hline
\end{tabular}

Source: research data

\subsection{Conclusions and Recommendations}

In conclusion, this paper reveals that despite of challenges of coffee production, farmers have continued with its production. Farmers perceive coffee production as a traditional crop, and therefore it is a cultural symbol. Nevertheless, farmers have admitted that they are gaining more from coffee than other crops. In addition, the gain of wealth from coffee production provides the means of investment to other food crops.

\section{References}

Banerjee, A., and E. Duflo. 2007. "The Economic Lives of the Poor.” Journal of Economic Perspectives 21 (1): 141-167.

Daniel (2013) Assessment of agricultural extension services in Tanzania. A case study of Kyela, Songea rural and Morogoro rural district. Report in Plant Sciences, Wageningen University, 23-25

Dixie, G. (1989), Horticultural Marketing: A Resource and Training Manual for Extension Officers, FAO Agricultural Services Bulletin, Food and Agricultural Organization of the United Nations, Rome, p1-5.

Dorward, A., Kydd, J., Poulton, C. (1998). Smallholder Cash Crop Production under Market Liberalization: A New Institutional Economics Perspective.CAB International, Wallingford;

Doomdooma Region of Tinsukia District, Journal of Agriculture and Life sciences, Vol. 1, No. 1; June 2014, 8290

FAO (2008): Agricultural and Food marketing management: Marketing and its role in economic development Regional Office, Africa, 25

Ellis, F (1996); Agricultural policies in developing countries, Cambridge University Press, New York, USA, 7879

Jayne et al. (2010): Principal Challenges Confronting Smallholder Agriculture in Sub-Saharan Africa, World Development Vol. 38, No. 10, pp. 1384-1398, 2010

Jayne et al., (2010). Land pressures, the evolution of farming systems, and development strategies in Africa: A synthesis. Food Policy, Volume 48, October 2014, Pages 1-17

Johnes, M. (2015):,The World Economic Forum AgendaMahanta and Konwa. (2014). Production and Marketing of Orange in Assam -A Study on

Masanjala, W and Papagerius C. (2008). Rough and lonely road to prosperity: a reexamination of the sources of growth in Africa using Bayesian model averaging. Journal of Applied Econometrics, Vol 23, Issue 5, August 2008, 671-682

Masood, A, Ellahi, N, Batool, Z (2012). Causes of Low Agricultural Output and Impact on Socio-economic Status of Farmers: A Case Study of Rural Potohar in Pakistan, International Journal of Basic and Applied Science, Vol. 01, No 02, October 2012. 343-351

Mhando, D.G; Itani, J. (2007): Farmers' Coping Strategies to a Change in Coffee Market after Economic Liberalisation: The Case of Mbinga District, Tanzania, African Study Monograph, Supplementary Issue No. 36: 39-58 March 2007.

Mhando, D.G; Haller, T; Ludi, E; Mbeyale, G: (2013). Adaptation to changes in the coffee value chain and price changes among coffee producers in Kilimanjaro, Tanzania, African Study Monographs, 34 (1): 27-56, March, 2013: http://www.africa.kyoto-u.ac.jp/asm/normal/asm_34-1.html

Mhando D. G (2014), Conflict as motivation for change: The case of coffee farmers' cooperative in Moshi, Tanzania, African study Monographs. Supplementary Issue (2014), 50:137-154

Raidimi and Kabiti (2017) Agricultural extension, research, and development for increased food security: the need for public-private sector partnerships in South Africa, South African Society of Agricultural Extension (SASAE), vol.45 No.1 Pretoria, 49-63 
Sapkota,D and Pokhrel,S (2010) Community based maize seed production in the hills and mountains of Nepal: A review; Agronomy Journal of Nepal (Agron JN) Vol. 1: 2010 pp.107-112

Saris, A; Morrison, J. (2010) Food Security in Africa: Market and Trade Policy for Staple Foods in Eastern and Southern Africa, FAO, Edward Elgar Publishing Limited, UK (chapter 3).

Schengen F.; Joanna, B; Keyzer, M, Halsema A, (2003) From Subsistence to Profit Transforming Smallholder Farms, Policy Food Report; Washington, D.C.: International Food Policy Research Institute (IFPRI). http://dx.doi.org/10.2499/9780896295582 (June 11, 2018)

TCB (2017). Midterm evaluation of Tanzania Coffee Development Strategy 2011-2021: Moshi, Tanzania.

Tracey-White, (2003). Planning and designing Rural Markets. Marketing and Extension Guide, No 4, FAO, Rome, 2-17

URT (2013). Agricultural Extension System in Relation to RIPAT Effort, Ministry of Agriculture Food Security \& Cooperative s 11th March 2013. Http://www.ripat.org/fileadmin/userupload/RIPAT _launch_Joyce_ Mvuna.pdf (11 June, 2018)

Winford H. Masanjala (2005) Cash crop liberalization and poverty alleviation in Africa: evidence from Malawi, Agricultural Economics 35 (2006) 231-24

WIPO (2010): WORLD INTELLECTUAL PROPERTY INDICATORS, 2010 report.

http://www.wipo.int/edocs/pubdocs/en /intproperty/941/wipo_pub_941_2010.pdf. (9 June, 2018) 